\title{
Exploring pre-service teachers' beliefs about teaching and learning grammar: Implications for teacher education
}

\section{Peter Oluwaseun Merisi}

Language and Arts Education, School of Education, University of KwaZulu-Natal, South Africa.

s.christson@yahoo.com (corresponding)

https://orcid.org/0000-0001-7753-8034

\section{Ansurie Pillay}

Language and Arts Education, School of Education, University of KwaZulu-Natal, South Africa.

Pillaya3@ukzn.ac.za

https://orcid.org/0000-0002-9174-0543

(Received: 13 November 2019; accepted: 3 March 2020)

\section{Abstract}

In this article, we argue that it is essential to acknowledge the beliefs with which pre-service teachers enter universities since their beliefs could shape how they teach in the future. In our qualitative study, underpinned by metacognitive and attribution theories, we consider English Education pre-service teachers' beliefs about learning and teaching grammar and the implications thereof for teacher education. The findings revealed that participants' beliefs were shaped by their experiences of the pedagogic practices in their schools. It became clear that the developers of teacher education programmes cannot assume pre-service teachers' competencies and should take cognisance of their backgrounds and levels of preparedness for university.

Keywords: beliefs, pre-service teachers, grammar teaching and learning, teacher education, metacognition theory, attribution theory

\section{Introduction}

We contend that it is essential to recognise and acknowledge the beliefs with which preservice teachers enter universities as well as those they develop during their teacher education programmes since their beliefs about teaching could shape how they teach in the future. We argue that until these beliefs and their causes are recognised and addressed, if necessary, our current teaching in schools may not improve. Naruemon (2013) has noted that it is important to research pre-service teachers' beliefs since one of the main goals of teacher education programmes is the modification and formation of the beliefs of pre-service teachers. 
Furthermore, Pajares (1992) has cautioned us to remember that pre-existing beliefs are capable of negating the efforts of teacher education programmes. Beliefs serve as a guide for teachers' selection of their future teaching practices and may contribute to helping them make sense of what they are studying (Richardson, 2003).

In our study, we considered English Education pre-service teachers' beliefs about learning grammar and the implications thereof for teacher education in South Africa. Many reviews of school teaching raise concerns about language (and grammar) teaching (Cajkler \& Hislam, 2006; Ramsay, 2004), including the need to increase teachers' knowledge about language. The United States of America, Australia, and the United Kingdom, for example, have proposed that in teacher education curricula more time should be given to learning grammar (Harper \& Rennie, 2009). In South Africa, the Department of Basic Education (1997) has acknowledged that English is very poorly taught, and a teacher union member has noted that African learners are disadvantaged because they are taught by teachers who are not always communicatively and linguistically competent in English (Kruger, Landsberg, \& Swart, 2013; Mafisa \& Van der Walt, 2002; Reed, 2014). Furthermore, the majority of these learners, for whom English is a second or third additional language, do not have sufficient exposure to the English language at home. Despite numerous attempts to improve the curricula since South Africa's independence in 1994, researchers and curriculum planners in this country are aware of the bleak state of English grammar learning and teaching (Henning \& Dampier, 2012) but we argue that we need to know the beliefs of pre-service teachers before we plan curricula or other improvements.

We explore the beliefs that pre-service teachers, who are studying to become teachers of English at a School of Education in KwaZulu-Natal, have about learning grammar in South African high schools and at university. We consider how pre-service teachers' own beliefs about learning grammar and their experiences of having learned it may influence their grammar teaching practices. We begin by reviewing the literature that has shaped the argument being put forward and then we consider the theoretical framework that underpins the study. We go on explain our methodology before discussing the findings of the study and offering concluding thoughts.

\section{Literature review}

The debate on the role that grammar knowledge plays in language learning is pervasive. Some scholars believe that language cannot be learned effectively without necessary exposure to the grammar of that language (Jones \& Chen, 2012), while others are of the opinion that language learning has nothing to do with knowledge of grammar, particularly explicit knowledge of it (Myhill, 2011; Wales, 2009). However, since this paper is not a contribution to this debate on the role of grammar, but an exploration of the beliefs of the preservice teachers of English about the teaching and learning of grammar, we limit ourselves accordingly. 
It is evident in the literature on teacher cognition that language teachers develop their beliefs about language learning, particularly grammar knowledge, throughout their lifetimes (Borg, 2011; Lortie, 1975). It is clear that pre-service teachers already have established personal theories and assumptions, about, and predispositions towards, grammar learning. One of the more contentious debates in studies about pre-service teachers' beliefs revolves around what constitutes their core beliefs, as opposed to their peripheral ones (Borg, 2006; Fleming, Bangou, \& Fellus, 2011; Pajares, 1992). Core beliefs are those that are capable of resisting changes or new ideas, while peripheral beliefs are those that can be easily challenged or changed (Samuel, 2008). Previous studies on teacher cognition have revealed three major factors that constitute pre-service teachers' beliefs about grammar learning or teaching; using Borg's (1999) classification of teachers' cognitions about grammar instruction, these factors can be summarised into the three categories of schooling, teacher education, and classroom experience. Since our study focuses only on pre-service teachers and not on in-service teachers, the first two categories are more relevant to it.

Studies have found that the pre-service teachers' own schooling and language learning experiences are important factors in the formation of their belief system particularly in relation to grammar learning (Busch, 2010; Fleming et al., 2011). Pre-service teachers bring with them both positive and negative images of teaching, from which they create categorisations of good and bad instructions. For example, Mattheoudakis (2007), in his investigation of pre-service English First Language (EFL) teachers, found that most of their beliefs about language teaching and learning, particularly in the teaching of vocabulary, grammar, and correct pronunciation, were rooted in their own language learning experiences as learners. Lortie (1975) coined the term "apprenticeship of observation" (p. 62) to refer to the quality of time students spend in the classroom acquiring their beliefs about learning and teaching that then serve them as models. Lortie added that this period consists of two types of memory: pre-service teachers' memories of themselves as students or learners; and their memories of their teachers. Johnson argues that these memories are powerful because they serve as "indelible imprint[s] on most teachers' lives and minds" (1999, p. 23).

Busch (2010) also identified the teacher education programme as another key element of preservice teachers' beliefs about how grammar ought to be learned. Studies have revealed that pre-service teachers' beliefs about the way grammar should be taught are also influenced by the type of teacher education they receive. Altan (2006) and Mattheoudakis (2007) have claimed that the teacher education programmes bring no or little change to those already established beliefs. In contrast, however, Busch (2010), and Özmen (2012) found that teacher education programmes can make a difference to pre-service teachers' beliefs about grammar learning. Mattheoudakis (2007) discovered that pre-service teachers use the information they have learned to reinforce their prior beliefs rather than challenging them. This, therefore, agrees with Samuel's (2008) and Phipps and Borg's (2009) argument that pre-service teachers' core beliefs are resistant to change. Studies have offered various reasons why teacher education has little or no influence on the growth of prior beliefs. Pajares (1992), for example, mentioned that prior beliefs are formed over a long period of time. Despite the ongoing debates on the impact of teacher education programmes on pre-service teachers' 
beliefs, Phipps and Borg (2009) have argued that "it is not enough . . . to identify differences or tensions between teachers' beliefs and practices. Rather, attempts need to be made to explore, acknowledge, and understand the underlying reasons behind such tensions" (p. 388). It is against this background that we sought to explore what the beliefs of English Education pre-service teacher are, and what they think led to such beliefs.

The study was underpinned by metacognitive and attribution theories. The metacognitive theory, proposed by Flavell (1979), relates to the individual's knowledge about his or her most basic mental states such as perceptions, feelings, and beliefs, among others. This theory focuses on the cognitive knowledge that people have about their own thinking (selfknowledge) and about other people, and the regulation of those cognitive processes. We found metacognitive theory to be appropriate for the present study given its focus.

Attribution theory places importance on people's explanations of their beliefs and experiences, and the attributions they make through their individual inferences to understand and interpret the causes they believe to lie behind their beliefs and understandings (Gabillon, 2013). Attribution theory is the systematic study of the perception of causality. According to Yang (2009), attribution theory accounts for how ordinary people make causal explanations or, in other words, about how they answer questions beginning with "why?" The theory looks at the impact of human beliefs on subjects' present and future efforts or practices. This theory posits that people seek meaning in their behaviour and in their world (Gabillon, 2013). The theory centres on how the social perceiver generates information about either their own behaviour or that of others, and how this information is interpreted to arrive at causal judgment of an event (Försterling, 2001). Thus, the beliefs about causes are of importance to the attribution theorists rather than the actual causes of behaviour. Attributions are made through certain systematic processes, and when they are made, they influence people's subsequent behaviours and emotional reactions (Försterling, 2001). This theory was deemed appropriate for our study aimed at understanding participant's explanations for their beliefs.

While metacognitive theory helped explain the cognitive knowledge that participants have about their beliefs surrounding teaching and learning grammar, the attribution theory clarified the meanings behind such beliefs.

\section{Method}

This study is located within an interpretive paradigm that regards knowledge as a social construct, and is grounded in a qualitative approach, which allows for rich reports that are necessary for interpretivists in order to understand the context (Willis, 2007). Narrative inquiry, situated within the qualitative approach and interpretive paradigm (Connelly \& Clandinin, 1990), serves as the research design. The main claim for the use of narrative in educational research is that humans are storytelling organisms who, individually and socially, lead storied lives. This research design was employed because it allowed the participants to tell their lived experiences of learning grammar in both written and spoken form. The design 
was useful in the interpretations of pre-service teachers' beliefs about how grammar should be learned and taught.

We used open-ended questionnaires, semi-structured interviews, and narratives as the research instruments for data generation. We worked with fourth-year students who were studying English education at the university under study, all of whom were purposively sampled from the English Major 420 class (the final module before they graduate) since the inclusion criteria included this along with their being on track to complete their degree that year. These fourth-year students were selected since they would have had almost four years' experience of grammar learning at the tertiary institution in addition to their prior experience of grammar learning at school. Moreover, these students were in the transition stage of being prepared for classroom teaching the following year. Questionnaires were administered, with their informed consent, to all the fourth-year students in the English Major 420 class. The module lecturer was contacted prior to this period and students were briefed about the study. Fifty students initially participated in the study, of whom 39 were African and 11 Indian, but only 11 of these continued for the remaining two sets of data collection. The reduction in the number of study participants to approximately $20 \%$ of the original total who were recruited for interviews and narratives was because some of them were not willing to be interviewed or to write the narratives in case they made grammar mistakes.

The questionnaires aimed to identify the biographical details of the participants and to explore their beliefs about learning and teaching English grammar since they were going to teach this area the following year. The semi-structured interviews and written narratives were employed to delve further into these beliefs.

We use thematic analysis, a qualitative data analysis method, to analyse the data as it came in. This kind of analysis is used for identifying, describing, analysing, and reporting themes and patterns within a data set in rich detail (see Braun \& Clarke, 2006; Smith \& Eatough, 2007). We used an inductive thematic analysis approach in order to provide a rich thematic description of participants' own narratives of their beliefs about grammar learning. Using Braun and Clarke's (2006) guidelines for conducting thematic analysis, all data emanating from this study was analysed through four stages. The first stage involved familiarising ourselves with the data and the background literature. The second stage involved generating initial codes by using labels that were conceptually meaningful to the data (see Duff 2008). Line-by-line coding was used to ensure attention to detail in the three data sources. The third stage included memo writing about thoughts that occurred during the coding and thematic analysis. The final stage entailed categorising themes.

The average length of the interviews was between 20 and 30 minutes. The interview-based data was transcribed by one of the researchers and two postgraduate students and the transcript was thoroughly checked by both researchers to ensure accuracy. Having done this, we analysed the narratives, interviews, and questionnaire data thematically, and chose the themes for analysis according to the frequency of their occurrence. Some of the themes that emerged from the analysis included grammar learning, explicit and communicative grammar teaching and learning, and content knowledge of grammar. 


\section{Discussion of findings}

There were two major findings from the study and they relate, as expected, to the pre-service teachers' beliefs about how grammar ought to be taught or learned, and their beliefs about their knowledge of the construct. Hence, in our discussion we focus on these beliefs about the explicit teaching of grammar, and on their beliefs about the communicative approach to teaching grammar. Then we look at their beliefs about their knowledge of grammar.

\section{Beliefs about the explicit teaching and learning of grammar}

Most of the questionnaire respondents were of the belief that grammar should be learned explicitly as a set of linguistic rules. Although this finding contradicts the belief of researchers such as Myhill, Jones, and Watson (2013) and Wales (2009), among others who emphasise the importance of the pedagogical content knowledge of grammar rather than reliance on the explicit teaching of the content knowledge of grammar, it corresponds with Sopin's (2015) findings about the role of explicit grammar teaching in language learning. In a study on students' perceptions about grammar teaching and learning in Libya, Sopin found that all the study participants strongly believed that grammar should be explicitly taught. In the present study, from the 43 questionnaire respondents who answered the question pertaining to the explicit teaching of grammar rules, 34 were of the opinion that grammar can be learned effectively only when taught explicitly. Seven responses were opposed to the explicit teaching of rules, while the remaining two were not sure how to answer the question. For example, one of the respondents (QR 40) who believed in explicit teaching declared that "grammar involves many rules and may end up confusing if not taught explicitly." This view concurs with that of Tütüniş (2012) who has said that explicit grammar instruction supplies the declarative knowledge of grammar thereby eradicating confusion in the language learning process. A questionnaire respondent (QR 24) was of the opinion that grammar is rulesembedded and that these rules may not be properly applied without explicit teaching. To this participant, it appears that the main purpose of explicit teaching of grammar is to eliminate confusion in the application of grammar rules. On this note, three others added that the approach has the tendency to eradicate confusion from the minds of the students. For instance, another questionnaire respondent (QR12) stated that the reason why it should be explicitly taught is "because no one is left confused but one gets a clear understanding." This is in agreement with the position that explicit instruction enables learners to acquire grammar they would not have learned on their own and that explicitness improves learners' accuracy over what normally transpires when there is no focus on form (see Wang, 2010). Wang has argued that explicitness is an unavoidable aspect of grammar teaching. It would appear that explicit grammar learning, according to these 34 respondents, is associated with clarity and understanding particularly in contexts in which students are unfamiliar with the English language.

Of the 11 interviewees, 7 also thought that grammar is best taught through explicit teaching, while 4 said it should not be explicitly taught. For instance, a participant (Interviewee 1) argued that grammar has "rules that need to be followed because when I think of grammar, I 
think of rules, I think of whole bunch of rules that need to be applied, and applied correctly in order to express yourself correctly." Another participant included that grammar learning "is a way in which you are taught how to use a language correctly and appropriately" (Interviewee $3)$.

Proponents of explicit grammar teaching have identified reasons why grammar rules should be explicitly taught. One reason is that explicit teaching compensates for lack of exposure to the target language as well as the lack of time to make learners notice certain grammatical and language forms and structures. Thus, explicit teaching leads to the awareness of target language forms during input (Noonan, 2004). The relevance of this to our study is that 78 percent of the study participants learned English as their second or additional language. Findings revealed that most of them had poor or inadequate exposure to English grammar both at home and at school, and therefore, they might be thinking of explicit grammar as a way of creating awareness, particularly of those aspects they deemed difficult. Furthermore, researchers, such as Nassaji and Fotos (2004) have suggested that another reason why grammar should be explicitly taught is the inadequacy of meaning-focused teaching approaches. They maintain that the exclusive focus on communication is not capable of providing learners with enough accuracy in the target language. For example, some of the study participants lamented that most of them, although they are in their final year of training for the teaching profession, were still making mistakes because of the lack of exposure to rich and explicit grammar instruction. Norris and Ortega (2005) have argued that explicit teaching leads to better learning of target structures, while Ellis (2010) has suggested that explicitness is characterised by a longer lasting effect. Other scholars are of the opinion that some focus on grammatical forms and error corrections are necessary for the development of high levels of accuracy in the target language (Scheffler 2012; Spada \& Tomita 2010). These opinions were reinforced by the participants' belief that grammar is best learned and taught through explicit teaching. We need to consider if their beliefs were shaped by their personal experiences of learning grammar.

\section{Beliefs about the communicative approach to grammar learning}

Thirty-four pre-service teachers answered the question about whether grammar can also be learned through communicative tasks. Of the 34 respondents, 25 believed that it could be learned this way while the remaining respondents had the opposite view. This result seems to contradict the largely-held view that grammar needs to be taught explicitly. Although these 25 respondents were of the belief that the communicative approach to teaching grammar is effective, they had different reasons for their responses. Nine questionnaire respondents said that grammar can be learned naturally. One of the respondents (QR 32) claimed that "learners pick on what is grammatically correct through communication and when they communicate it comes to them naturally." This view relates to the natural approach to language learning that relies on emphasis being placed on the intuitive process which is presumed to occur when the natural language learning ability is appropriately awakened (Krashen \& Terrell, 1983). These scholars presume that meaning is more important in language learning than form, and this approach encourages students to listen to their teachers from the start of the class when they 
are using the target language. Moreover, this approach holds that grammar in a second language can also be learned as was grammar in the first language.

Here we have evidence of the assumption that through listening, grammatically correct sentences or expressions can be learned or acquired either consciously or unconsciously, and that the ability to apply grammar rules naturally can also come about through communication and not necessarily only through an explicit teaching of grammar. This belief is rooted in the focus-on-meaning approach to grammar teaching and learning. This approach, according to Chowdhury (2014), follows the incidentally-oriented classroom instructions with emphasis on meaning in any communicative task. It thus holds that grammar can be learned without explicit teaching and planned activities (in contradiction to the study participants' previous answers). Therefore, emphasis is placed on the learners' ability to analyse language and deduce grammar rules at a subconscious level, depending on their exposure to correct language input and environment. Unfortunately, the situation is not similar for all students in the South African context and for most of the study participants in that they were not exposed to rich and meaningful second language learning contexts. In fact, many of the study participants stated that they had their early grammar learning experiences in schools located in rural areas. Unfortunately, a major characteristic of these schools is that English language is poorly taught since some teachers are under-qualified while some do not have the necessary grammar competence (Kruger et al., 2013).

A pre-service teacher's (QR 32) argument that through mere listening learners are able to pick up on what is grammatically correct, points to the grammatical competence dimension of the approach. Some participants held that the communicative approach is the best method to correct grammar mistakes. Another respondent (QR 23) claimed that "it is easy to correct someone when you are having a conversation and it is something they hardly forget." Given this statement, there appears to be a shift here from focusing primarily on meaning to focusing on form. This view is in agreement with Littlewood's (1981) argument that one of "the ... features of communicative language teaching is that it pays systemic attention to functional as well as structural aspects of language, combining these into a more fully communicative view" ( p. 1). This view expands the scope of communicative language teaching (CLT) beyond a mere focus on meaning but adds that until the structural aspect of grammar is included, there cannot be a fully communicative view of grammar. This preservice teacher's argument that learners are able to pick up on what is grammatically correct through listening relates to the grammatical competence dimension of the approach, which Chomsky (1957) referred to as linguistic competence.

Four questionnaire respondents believed that one of the advantages of the CLT approach is that it enhances learners' listening skills and serves as the link between listening and speaking. One respondent (QR 18) said that "pupils listen when we/other[s] speak and are able to speak out grammatically correct sentences from what they hear." This view relates to the effect of a teachers' influence on their learners. This influence is what Lortie (1975) calls the "apprenticeship of observation" (p. 62). It would appear that this participant was arguing that the communicative approach gives learners an opportunity to listen to how correct 
sentences are constructed and that it gives them the opportunity to practice orally what they have learned. Such a view may prove helpful in a classroom setting with a teacher who has a good command of the language, but if the majority of the teachers of English do not have a mastery of the language and teach in schools located in rural areas, this might not be the case (see Mafisa \& Van der Walt, 2002; Silva, 1997). If the speaker (teacher) is deficient in knowledge of grammar, can one then say that the listeners (learners) will be able to learn how to construct grammatically correct sentences from the conversation?

Research shows that English language is poorly taught in South African schools and one of the reasons for this situation is the fact that some of the teachers themselves are not competent in the language they teach, as mentioned above. Some of these teachers do not pronounce English words correctly while others often skip the grammar lessons since they are not competent in this area (Kruger et al., 2013; Mafisa \& Van der Walt, 2002). Some English language teachers often resort to their mother tongue to teach English grammar. Learning to speak grammatically in such a scenario is difficult if not impossible. For instance, in her description of a bad grammar learning experience, one of the respondents (QR 14) argued that grammar teaching is bad "when you plan to teach grammar and you yourself speak bad or poor English and end up confusing the learners." Unfortunately, not only does this use of poor English lead to confusion, but the teacher's lack of grammar knowledge may contribute to students' belief system about how grammar should be taught or learned. All these still point to the place of rich and correct language input and environment such as the classroom in grammar learning. One of the interviewees (Interviewee 6) lamented her grammar learning experience in school. She said,

Sometimes teachers used code-switching when they taught us grammar. Then, when they teach, there were so many mispronunciation[s] of words and if you get to know the word, you will discover the whole meaning becomes changed . . . [Concerning] spelling, sometimes it happen[ed] that the teacher also spelled some of them [incorrectly].

All these form the pre-service teachers' memories of themselves as learners and their memories of their teachers (see Lortie, 1975).

In summary, $73 \%$ of the pre-service teachers held that grammar should be learned through communicative tasks and only $27 \%$ disagreed with this belief. Nevertheless, we found that most of those who first supported the explicit teaching of grammar joined those who thought that grammar might be learned through communicative tasks as well. While this looks like a contradiction, it could be viewed more as a recommendation for combining the strengths of the two approaches. This view might have resulted from their experiences of learning grammar both in school and at university.

\section{Pre-service teachers' beliefs about their own grammar knowledge}

Although the pre-service teachers who participated in this study had, to an extent, different beliefs about grammar teaching and learning, their responses, when asked about their own 
knowledge of it, seemed to be fairly consistent. We found that most of the study participants believed that they did not have a good knowledge of grammar and they believed that this may impact negatively on their teaching practices in the future.

We found that the way the subject of grammar is being approached in the teacher education programme, particularly in the English language discipline, influenced the participants' beliefs about what constitutes a good knowledge of grammar as well as their beliefs about their own knowledge of the construct. For example, nine of the interviewees thought that they were lacking in the knowledge of grammar and this was attributed to their lack of adequate exposure to the explicit teaching of grammar both in school and in the university teacher education programme. When asked about his experience of learning grammar in school and at the teacher education programme, one participant (Interviewee 1) described it as demotivating. He said, "It was de-motivating and especially because I had a bad grammar experience in school. I would have expected to be taught grammar in-depth at the university so that I will be a competent teacher." This student seemed to be linking competency in grammar teaching or a sound knowledge of grammar to explicit teaching. Also, he appeared to have come into the teacher education programme with the expectation of being equipped with the in-depth (content) knowledge of grammar which he believed he was not given in school. This view is similar to that expressed in a narrative essay (NE 9), in which the participant commented that

grammar knowledge is essential to us and even the learners we intend to teach. We are expected to teach in schools the very same thing we were not taught at school. We are robbed [at the university] like we were robbed in high school.

Following from this view, pre-service teachers are expected to teach grammar, but their prior and present grammar learning experiences may put them at a disadvantage in that it is difficult for them to teach what they do not know. Another participant (NE 10) who claimed to have had a little grammar content knowledge complained,

When I got to grade 10 I realised that the more I practised grammar, the more I understood and applied it, but as soon as I got to the university I lost the love for grammar because ... there are no specific grammar modules. So, grammar practice and application slipped through the cracks easily.

This comment raises concerns regarding what the teacher education programme is doing to remedy the content knowledge-based difficulty that the pre-service teachers seem to have in relation to their preparation to teach grammar. For another participant (Interviewee 1), students may lose the desire and passion to teach the grammar section if attention is not given to how the construct is being addressed in the curriculum and how it is being taught to the pre-service teachers. Another participant (Interviewee 2), while responding to the question about her level of understanding/ knowledge of English grammar, said,

I am not perfect in my English grammar. I feel it most especially when I go to

Teaching Practice, where I need to teach grammar. I first have to go back and do 
research because I have only done grammar at school and mostly, I have forgotten how it [was] done. I can say I am not proficient in my English grammar.

All these concerns about the participants' lack of sound grammar content knowledge seem to have been attributed to factors out of their control; such factors include the lack of explicit teaching of grammar in schools and at university. While explaining the factors affecting people's belief systems, Heider argued that in "common-sense psychology, the result of an action depends on two sets of conditions; factors within the person and factors within the environment" (1958, p. 82). Heider claimed that one's belief system is a function of two factors or causes - dispositional and situational. The former, described as internal causes, are attributed to factors within a person, while the latter (also described as external causes) are attributed to factors outside of the person, such as social context and roles (Augoustinos, Walker, \& Donaghue, 2007). Thus, it can be said that these students believed that their inadequate grammar content knowledge resulted from their prior grammar learning experiences.

It could therefore be understood that the participants were concerned that they did not engage with grammar content. One of the questionnaire respondents (QR 29) lamented that "after completing six modules in the school of language, we received nil training," Another respondent (QR 26) said, "I feel I need to be taught more about grammar." One participant (Interviewee 1) believed that he was very good at grammar. Nevertheless, he connected his success in grammar learning to personal efforts rather than to the contributions from schools and teacher education programmes. He said,

In my second year, I remember I had to do a lot on grammar in my writing practices, yet we were never taught grammar so, it was quite challenging, but at the same time it was really good because I had to go back, and sit with myself and do research and start reminding and teaching myself. Yes, I developed myself, so I wasn't taught by the university.

From the above extract, it is clear that this student attributed his success in grammar learning to personal development (a dispositional cause). Nevertheless, he still attributed his struggles with the content knowledge of grammar to the failure of the teacher education programmes to provide rich exposure to the explicit teaching approach. The findings above and the disposition of the study participants towards the content of their teacher education programme, particularly in the teaching of grammar, relate to Mattheoudakis's (2007) finding that that none of the study participants found the content of their teacher education programmes useful. We therefore argue that we need to engage with the beliefs of the preservice teachers if we are to make our teaching practices in the teacher education programmes useful and relevant.

\section{Implications for teacher education}

The findings of this study have implications for the current practices in teacher education institutions. First, the policy informing the English education curriculum should be revisited. 
The present curriculum focuses only on the communicative approach to grammar teaching without any explicit teaching of grammar whereas the majority of the students we are training to become teachers of English at the university under study are predominantly second language users of English who have little or no access to the language outside of the classroom. The curriculum therefore needs to consider who the pre-service teachers are, and needs to ascertain their knowledge in general, and the grammar knowledge in particular with which they arrive at teacher education programmes. We need to consider how pre-service teachers are taught grammar in primary and secondary schools, and modules need to be designed to enable these pre-service teachers to teach grammar correctly and effectively in the future. We recommend that more studies should focus on how grammar is being taught in South African schools since this will assist curriculum designers in teacher education programmes to identify the knowledge gap, and work to bridge it.

Second, modules should be designed to address the kinds of beliefs and knowledge that preservice teachers bring with them to the teacher education programmes. Doing this will allow the teacher educators to become aware of the challenges facing these pre-service teachers and will enable them to strategise on how to address such challenges. In other words, until English teacher educators see grammar knowledge as an integral part of the teacher education programme and react to this accordingly, we will continue to graduate teachers of English who will teach English grammar as poorly as it is being taught currently in schools. While the study was primarily concerned with the beliefs of pre-service teachers and did not elicit the views of teacher educators or ascertain their beliefs, it is clear that the importance of understanding teacher educators' beliefs about grammar teaching is equally important. This is, potentially, a follow-up study that could be undertaken.

Overall, it may be argued that research findings need to inform the Teacher Education curriculum, and that the pre-service teachers also need to understand what research studies argue for regarding the teaching of grammar.

\section{Concluding thoughts}

We re-affirm our contention that it is essential to identify and respond to the beliefs (about the explicit teaching of grammar) with which pre-service teachers enter universities since their beliefs could determine how they teach (grammar) in the future. We argue that until these beliefs and their causes are recognised and addressed, our current teaching in schools will not improve. The importance of metacognitive experiences and an understanding of the complex and contested nature of teaching and learning is apparent in this study. Furthermore, we have highlighted the crucial roles of teachers and teacher educators along with the importance of how they shape students' knowledge base. Assumptions by teacher educators of student knowledge and preparedness need to be confronted and interrogated, and engagement with students' beliefs about all aspects of the subject are essential if we are to ensure that teaching becomes effective in schools. In not ascertaining pre-service teachers' beliefs and levels of awareness, teacher education will contribute to the replication of the poor teaching and learning practices prevalent in many South African schools today. 


\section{References}

Altan, M. Z. (2006). Beliefs about language learning of foreign language-major university students. Australian Journal of Teacher Education, 31(2), 45-52. Retrieved from http://ajte.education.ecu.edu.au/issues/PDF/312/Altan.

Augoustinos, M., Walker, I., \& Donaghue, N. (2007). Social cognition: An integrated introduction. London, UK: Sage.

Borg, S. (1999) Teachers' theories in grammar teaching. ELT Journal, 53(3), 157-167.

Borg, S. (2006). Teacher cognition and language education: Research and practice. London: Continuum.

Borg, S. (2009). Language teacher cognition. In A. Burns \& J. C. Richards (Eds.), The Cambridge guide to second language teacher education (pp. 163-171). Cambridge, UK: Cambridge University Press.

Borg, S (2011). The impact of in-service teacher education on language teachers' beliefs. System, 39(3), 370-380.

Braun, V., and Clarke, V. (2006). Using thematic analysis in psychology. Qualitative Research in Psychology, 3(2), 77-101.

Busch, D. (2010). Pre-service teacher beliefs about language learning: The second language acquisition course as an agent for change. Language Teaching Research, 14(3), 318337.

Cajkler, W., \& Hislam, J. (2002). Trainee teachers' grammatical knowledge: The tension between public expectations and individual competence. Language Awareness, 11(3), 161-177.

Chomsky, N. (1957). Syntactic structures. The Hague, NL: Mouton.

Chowdhury, F. F. N. (2014). Effects of form focused instructions on outcomes in EFL learning: Teachers' and students' perspectives (Unpublished master's thesis). BRAC University, Dhaka, BD.

Connelly, F. M., \& Clandinin, D. J. (1990). Stories of experience and narrative inquiry. Educational Researcher, 19(5), 2-14.

Duff, P. (2008). Case study research in applied linguistics. New York, NY: Lawrence Erlbaum.

Ellis, R. (2010). Does explicit grammar instruction work? Ninjal Project Review, 1(2), 3-22. 
Flavell, J. H. (1979). Metacognition and cognitive monitoring: A new area of cognitivedevelopmental inquiry. American Psychologist, 34(10), 906-911.

Fleming, D., Bangou, F., \& Fellus, O. (2011). ESL teacher-candidates' beliefs about language. TESL Canada Journal, 29(1), 39-56.

Försterling, F. (2001). Attribution: An introduction to theories, research and applications. East Sussex, UK: Psychology Press.

Gabillon, Z. (2013, November). A Synopsis of L2 Teacher Belief Research. Paper presented at the Belgrade International Conference on Education, Belgrade, SRB. https://hal.archivesouvertes.fr/file/index/docid/940593/filename/1._Z.Gabillon_A_Sy nopsis_of_L2_Teacher_Belief_Research_BICE_Conference.pdf

Harper, H., \& Rennie, J. A. (2009). I had to go out and get myself a book on grammar: A study of pre-service teachers' knowledge about language. Australian Journal of Language and Literacy, 32(1), 22-37.

Heider, F. (1958). The psychology of interpersonal relations. New York, NY: Wiley.

Henning, E., \& Dampier, E. (2012). Linguistic liminality in the early years of school: Urban South African children 'betwixt and between' languages of learning. South African Journal of Childhood Education, 2(1), 100-119.

Johnson, K. E. (1999) Understanding language teaching: Reasoning in action. Boston, MA: Heinle \& Heinle.

Jones, P., and H. Chen. 2012.“Teachers'Knowledge about Language: Issues of Pedagogy and Expertise."Australian Journal of Language and Literacy 35 (1): 147-168.

Jones, P., \& H. Chen. (2012). Teachers' knowledge about language: Issues of pedagogy and expertise. Australian Journal of Language and Literacy, 35(1), 147-168.

Krashen, S. D., \& Terrell, T. D. (1983). The natural approach: Language acquisition in the classroom. London, UK: Prentice Hall Europe.

Kruger, D., Landsberg, E., \& Swart, E. (2013). Addressing barriers to learning: A South African perspective. Pretoria, RSA: Van Schaik.

Littlewood, W. (1981). Communicative language teaching. Cambridge, UK: Cambridge University Press.

Lortie, D. C. (1975). Schoolteacher: A sociological study. Chicago, IL: University of Chicago Press.

Mafisa, P. J., \& Van der Walt, J. L. (2002). Grammatical competence of ESL teachers. Per Linguam, 18(1), 15-26. 
Mattheoudakis, M. (2007). Tracking changes in preservice EFL teacher beliefs in Greece: A longitudinal study. Teaching and Teacher Education, 23, 1272-1288.

Merisi, P. O. 2017.“English Education Pre-Service Teachers'Beliefs about and Experiences of Learning Grammar.”Unpublished Ph.D dissertation, University of KwaZulu-Natal, South Africa

Myhill, D. A. (2011). Living language, live debates: Grammar and standard English. In J. Davison, C. Daly \& J. Moss (Eds.), Debates in English teaching (pp. 63-77). London, UK: Routledge.

Myhill, D., Jones, S., \& Watson, A. (2013). Grammar matters: How teachers' grammatical knowledge impacts on the teaching of writing. Teaching and Teacher Education, 36, 77-91.

Naruemon, D. (2013) Thai pre-service teachers' beliefs about the learner-centred approach and their classroom practices (Unpublished doctoral dissertation). Newcastle University, London, UK).

Nassaji, H., \& Fotos, S. (2004). Current developments in research on the teaching of grammar. Annual Review of Applied Linguistics, 24, 126-145.

Noonan, F. J. (2004). Teaching ESL students to "notice" grammar. The Internet TESL Journal, 10 (7). http://iteslj.org/Techniques/Noonan-Noticing.html.

Norris, J. M., \& Ortega, L. (2005). Does type of instruction make a difference? Substantive findings from a meta-analytic review. University of Michigan: Language Learning Research Club. Retrieved from http://onlinelibrary.wiley.com/doi/10.1111/j.14671770.2001.tb00017.x/pdf

Özmen, K. S. (2012). Exploring student teachers' beliefs about language learning and teaching: A longitudinal study. Current Issues in Education, 15(1), 1-15.

Pajares, M. F. (1992) Teachers' beliefs and educational research: Cleaning up a messy construct. Review of Educational Research, 62(3), 307-332.

Phipps, S., \& Borg, S. (2009). Exploring tensions between teachers' grammar teaching beliefs and practices. System, 37(3), 380-390.

Ramsay, G. (2004). Report on future directions for secondary education in the Northern Territory. Darwin, AU: Charles Darwin University, Department of Employment, Education and Training.

Reed, Y. (2014). Initial teacher education research project: Report on English courses for intermediate phase student teachers at five universities. Johannesburg, RSA: JET Education Services. 
Richardson, V. (2003). Preservice teachers' beliefs. In J. Raths \& A. C. McAninch (Eds.), Teacher beliefs and classroom performance: The impact of teacher education (pp. 122). Greenwich, CT: Information Age.

Samuel, M. (2008). Accountability to whom? For what? Teacher identity and the force field model of teacher development. Perspectives in Education, 26(2), 3-16.

Scheffler, P. (2012). Theories pass. Learners and teachers remain. Applied Linguistics, 33(5), 603-607.

Silva, P. (1997). The lexis of South African English. Reflection of a multilingual society. In E.W. Schneider (Ed.), Englishes around the world: Studies in honour of Manfred Gorlach (pp. 159-176). Amsterdam, NL: John Benjamins.

Smith, J. A., \& Eatough, V. (2007). Interpretative phenomenological analysis. In E. Lyons \& A. Coyle (Eds.), Analysing qualitative data in psychology (pp. 35-64). London, UK: Sage.

Sopin, G. (2015). Students' perceptions of grammar teaching and learning in English language classrooms in Libya. Journal of Research and Method in Education, 5(2), $67-72$.

Spada, N., \& Y. Tomita (2010). Interactions between type of instruction and type of language feature: A meta-analysis. Language Learning, 60(2), 1-46.

Tütüniş, B. (2012). Grammar in EFL pedagogy: To be or not to be: Explicit or implicit grammar instruction in EFL. International Journal of Humanities and Social Science, 2(5), 120-122.

Wales, L. (2009). Reviving the dead butler? Towards a review of aspects of national literacy strategy grammar advice. Language and Education, 23(6), 523-549.

Wang, S. C. (2010). Chinese language education in the United States: A historical overview and future directions. In J. Chen, C. Wang \& J. Cai (Eds.), Teaching and learning Chinese: Issues and perspectives (pp. 3-32). Charlotte, NC: Information Age Publishing, Inc.

Willis, J. W. (2007). Foundations of qualitative research: Interpretive and critical approaches. London, UK: Sage.

Yang, S-H. (2009). Using blogs to enhance critical reflection and community of practice. Educational Technology \& Society, 12(2), 11-21. 